Journal of Social Sciences 5(1): 76-79, 2009

ISSN 1549-3652

(C) 2009 Science Publications

\title{
The Effect of Banks Merger on Electronic Banking Services Competency
}

\author{
Ahmad Zakaria Siam \\ Al Balqa Applied University, Amman College for Administrative and Financial Sciences, \\ Government Sector, Jordan, P.O. Box 922806, Amman, Jabel Al Hussein
}

\begin{abstract}
Problem statement: This study is conducted to present benefits and consequences of latest technology used in banking industries. In addition, it has focused on the dynamics of banking sector, electronic banking services and new courses especially with mergers that constitute most of these mechanisms. Approach: The study discussed this new activity and the extent of response level of services while the need, wants and demands of customers are met. Furthermore, how banks deal with such services while taking into consideration cost reduction and ultimate higher profits and to achieve excellent performance. Results: The results revealed that banks consolidation helps the new entity to adopt many new systems to make its operations more effective and more rapid fast. Some of these systems: The adoption of electronic services by banks. Conclusion/Recommendations: This can be achieved as a result of funds and skilled human resources availability and bank consolidations lead to increase the customers quantitative and qualitative along with their increased loyalty to the bank as a return for better services they receive and bank consolidation help banks to expand their electronic services such as automatic teller and visa card to the adoption of the internet as means to expand modern services to informed customers.
\end{abstract}

Key words: Bank merger, industry, economic inflation

\section{INTRODUCTION}

One of the most important trends affecting the financial service industry is consolidation. The USA market saw a merger boom in 1996; in Europe too, the same process culminated in 1997, with the merger between the Swiss banks UBS and SBC which has let to the creating of one of the largest banks in the world. The first months of 1998 saw the creation of the world's largest financial group- Citigroup-formed by the merger between Citibank and Travelers. This trend is likely to continue, at least for the foreseeable future ${ }^{[1]}$.

Consolidations take place due to the following reasons:

- To take advantage of economies of scale. These are horizontal mergers or acquisitions (e.g., two or more institutions of the same type merge)

- To have access to distribution channels. This is referred to as inter industry consolidation. For example, large insurance companies often seek a fast way to access a widespread network of points of sales, such as bank branches, through which they can sell their products

- To widen the range of products that the bank can offer both actual and potential clients. This process is known as contamination and can be achieved by entering into a new market. For example, the acquisitions of investment banks by commercial banks are aimed at widening the services offered by the parent bank through its business units (they may also be and often are legal entities that are separate from the acquiring bank). Entering into a new market through an acquisition is often much easier than starting a new business from scratch

- To enter a new geographic market. This type of consolidation is known as international diversification. For a foreign commercial bank, there are significant barriers to entry, to any national market because it is difficult to establish an efficient and effective network of branches in foreign countries in a limited period. Most often, acquiring a domestic bank is the only feasible way to access that market. In addition, foreign banks face regulatory restrictions in many countries. When allowed, acquiring a domestic bank is a way to circumvent these regulations ${ }^{[1]}$

Furthermore, bank consolidation has started when giant bank in different spots of the world entered into fierce competition in order to enhance its competencies and better their services. In addition, consolidation or mergers have come to existence as means to solve 
several banking problems such as low profitability and inability to compete effectively Thus, bank consolidation increased rapidly especially in the United States and Europe. This phenomenon has prevailed among giant banks as well as smaller ones.

The consolidation trend has achieved the expected results include: Strengthening banks capital bases, secure more cash flow and the provision of differentiated banking services. It must be noted that consolidation process is accompanied by Information revolution and technology. Consequently; banks have taken advantage of such technology, the internet in particular, while spending substantial amount of money in order to obtain such technology. Thus, consolidation supported by technology enabled bankers to provide exemplary and various types of services and products. In return, banks profits soared and their success has become as a benchmark to other industries in general and banking in particular to follow the same or similar path namely: Consolidation embodied with technology.

Gains from this study are acknowledged by derivation components. Whereas, the study consists of two important parts of banking activity: First, it discusses the banking consolidation (mergers), reasons and characteristics. The second part discusses the competency of contemporary banking services. At the mean time, it clarifies the extent of competency in adopting these services by banks. Under banks consolidation, modern banking services imposed itself on the industry's arena in order to enhance the ability for banks to face competition and global financial and banking, operations.

In addition, banking industry has found itself in front of new realm which has been imposed by digital and technology revolution to transform operations mechanisms from traditional banking into electronic one. Thus banking features and characteristics have witnessed drastic changes in the developed countries in particular. From the aforementioned the importance of this study has been derived.

Approach: The present study aims at examining the extent of electronic banking services competency result from banking consolidation. Furthermore, the study discusses this new activity and the extent of response level of services, while the need, wants and demands of customers are met. Furthermore, how banks deal with such services while taking into consideration cost reduction and higher profits. Ultimately, achieving excellent performance.

Consequently, the study's objectives lie in the answers of the following questions:
- What is banking consolidation and its motives?

- What are the electronic banking services and what is the major reason for banks to steer its operations toward providing electronic banking services? By doing so, do banks face obstacles and hindrances?

- Does the prevailed legal framework for electronic banking services is enough to provide a sufficient protection for information systems of banks? Do banks have electronic software and human skills needed to keep pace with global progress and achieve banking differentiation within banking consolidations? 4-What is the extent of the provided banking services competency within banking consolidation?

Our discussion is based upon the test of the following hypotheses:

- There is contrast relationship between banking consolidation and the provided banking services competency, Banking consolidation affects positively on banks readiness, electronic software availability and qualified human resources to provide modern banking services

- The study's population consists of all consolidated banks in Jordan which have web sites

\section{MATERIALS AND METHODS}

Consolidation means the unification of two organizations interests or more. This interest in unity occurs through full merger or integration between two more companies to have a new entity in their place or to have one company acquires another. Consolidation can be whole or partial or whole or partial control or with or without consent. From legal perspective consolidation, means that the merger of small sized organization with another larger one. It results in the disappearance of the smaller organization.

This type of merger is completed through the following mechanisms: either the larger company buys all the shares (stock) of the smaller one, or to sell all its stock in order to buy stocks of the new company; or to buy the smaller company's assets while stockholders work to liquidity their company.

Consolidation or merger is a feature or image of strategic alliance. Consolidation is put into practice as a means of solutions of banks problems, shaky banks and the problem of internal and external debts. Furthermore, bankers and financial experts and analysts believe that consolidation is the cure for many problems that a bank faces, mainly lower rate of profitability, weakness in its financial base and inability to compete. 


\section{J. Social Sci., 5(1): 76-79, 2009}

There will be many success stories if bank mergers prove the validity of the above mentioned claims, small organizations in particular, whereas many people believe that these organizations are incapable to provide sufficient and better services by itself. Thus their consolidation would be very beneficial to them and to customers.

Banking consolidation aims at the following:

- Secure money resources along with proper conditions which enable the consolidated banks to provide various and better services. This would increase bank profitability, reputation and customer satisfaction. Consolidated banks would have better tools, mechanisms, plans, strategies and skilled human resource to have competitive advantage, economy of scale, better market share and position. Ultimately, better profits

- Banking sector would be more effective and more active as a sector contributes effectively in exports growth through the cooperation with business people of the organization. By doing so, there will be better research and development, more studies and research which may provide businesses and other sectors of economy with beneficial information about export, foreign markets, risks, currency exchange and host of other issues which concern exporters and businesses

Present researcher exerted substantial efforts while trying to collect the needed data and information to the study. One of these data sources is a review of previous studies in this field.

During research process, many interesting things the researcher faced with, this particular subject is understudied in Jordan due to the fact that there is virtually very few or none consolidation between financial institutions in Jordan. Banks in Jordan seem to operate on individual basis with no cooperation among them. Family owned and operated such as Arab Bank the largest in the region owned by Shuman family Ahli Bank owned by Mu'asher family and so Forth. On the other hand, banks merger in Europe and the USA is common occurrence. Consequently, the relevant literature is enriched with many studies, research, repots and other publication from out of Jordan.

The other interesting thing is that there are some Arabic publications by Arab authors in form of books. These books talk about banks mergers briefly from western point of view. The main thing in this regard, these books talk about foreign banks or organizations acquisition by Arab investors mainly from the Gulf States and Saudi Arabia.
For the aforementioned reasons, current researcher will cite several previous studies that conducted out of the Arab world:

A study by Jyoti Gupta and Alain chevalier entitled (Effects of Banks Mergers and Acquisitions in Europe): the case of BNP.

Authors gave a systematic overview of the possible motives and outcomes for mergers between different types of banks. Analyzing the value effects of mergers and acquisition such BNP and Paribas merger. The analysis found that there was synergy in cost and profitability, efficiency as well as on improvement in risk profile of the bank following the merger. The finding of BNP- Paribas 's abnormal returns agree with most empirical studies conducted in the field which show that the gains of the targets, shareholders are at the expense of the acquires shareholders, the BNP, Sociate General and Paribas.

In his study "the Effect of New Technology in payment services and others on banks Intermediation" $(15.3 .2003)^{[4]}$, dual approaches are used with four variable inputs the general model includes random coefficients to capture heterogeneity in the production technology across banks. The results showed that the move towards electronic payment services has decreased average costs, increased the economies of scale in the production of deposits more than in the deposits more than in the production of loans.

As a result of technology and consolidation bank seeks to obtain the following gains: Economies of scale which is important in investment, cost cutting, diversification, economies of scope, reusability of information, better product mix and strategic reasons such as increased competition and other benefits such as entering new geographic area.

A study entitled "Bank Austria, a Decade's Experience with Mergers." ${ }^{[2]}$ This starts with "Merger generates growth; Bank Austria is the result of the 1991 merger between Zentralsparkasse Wien (Vienna) and Oster-Reichische Handerbank. Five years later the union was followed by the acquisition of a credit analyst. This means that two brands-one organizations are two completely different worlds in terms of systems, processes and products. This coexistence yielded substantial potential for synergies. However, later they consolidated all of their legacy systems and processes "one process, one product and system. Beside the financial gains, management also benefited from the merger process, with changes in decision-making processes and the development of a new vision for the future helping to motivate the entire Bank Austria Leadership team, In addition, it has been claimed that the change management process as a guarantee for 
success. They proved the validity of this claim (http://www.accenture.com).

Merger policy in Banking-Household behavior at Depository Institutions (8-14-2002) ${ }^{[3]}$.

This study was conducting to examine the possibility of household leave of banks after a merger. The study showed the reflective action on households after merger of banks and what impact may occur by them. Although bank services have improved towards better performance and alert due changes or reactions by households.

The above mentioned previous studies are just sample from a huge pool of studies which the magnitude of this study doesn't allow expanding to.

Banks merger is a fascinating move toward economic inflation and service enhancement due to customer satisfactory. However most of them show strong evidence that banking service consolidation works as an effective tool to gain many benefits and to resolve many problems the banks may face.

\section{RESULTS}

- Banks consolidation helps the new entity to adopt many new systems to make its operations more effective and faster. Some of these systems: The adoption of electronic services by banks. This can be done as a result of funds and skilled human resources availability

- Bank consolidations lead to increase the customers quantitative and qualitative along with their increased loyalty to the bank as a return for better services they receive

- Bank consolidations help banks to expand their electronic services such as automatic teller and visa card to the adoption of the internet as means to expand modern services to informed customers

\section{DISCUSSION}

Merger among banks have proven its effectiveness as means to expand businesses, enter into national markets and provide additional assets and funds.

Bank manger is a common business activity in Europe and the USA; however it is very rare occurrences in the developing countries such as Jordan (The case study in this research). Banking sector in Jordan is owned entirely by prominent Jordanian families; with little investment by Arab or Foreign investors. Although Jordanian legislations allow foreign investors to own up to $100 \%$ of companies securities and bonds including banking sector. However, banks in
Jordan operate independently without allowing any take overs, consolidations or merger to happen, despite of the tremendous benefits which may banks experience as a result of merger or consolidation.

\section{CONCLUSION}

Jordan as a developing country has an advanced banking system in comparison with other countries in the region. This progress is due to the political and economic stability which Jordan enjoys for a long time. Thus, Jordan is directing its economy towards globalization and free market including its local banks. As a result, banks are using technology to provide better services. As study's recommendation banks should do the following:

- Banks should launch campaigns to "educate" people about the benefits of electronic banks and to increase their trust in such banks

- Banks should invest in electronic services, provide skilled people for that or train the eligible ones

\section{REFERENCES}

1. Edelheit, J.A. and M.R. Miller, 1997. Electronic commerce comes to the net. BT Technol. J., 15: 24-31. DOI:10.1023/A:1018624421938

2. Trask, N.T. and M.V. Meyerstein, 1999. Smart cards in electronic commerce. BT Technol. J., 17: 57-66. DOI: 10.1023/A:1009624303146

3. Unitt, M. and I.C. Jones, 1999. EDI-the grand daddy of electronic commerce. BT Technol. J., 17: 17-23. DOI: 10.1023/A:1009664017258

4. Jenkins, P.A., 1999. Electronic commerce in the real world. BT Technol. J., 17: 72-77. DOI: 10.1023/A:1009628404054 